\title{
MYOSITIS OSSIFICANS PROGRESSIVA
}

\author{
E. FLETCHER AND M. S. MOSS \\ From the Belfast City Hospital, Northern Ireland
}

Myositis ossificans progressiva is a rare disease, and most observers have described only single cases in their own experience. The most recent comprehensive survey of the condition has been given by Lutwak (1964), according to whom about 260 cases fitting the description of the disease have appeared in the literature since about 1670 . The aetiology of the disease remains unknown, but McKusick (1960) considered that fundamental disorder resided in connective tissue, and he adopted the name fibrodysplasia ossificans progressiva, a terminology first suggested by Bauer and Bode (1940). Nevertheless the term "myositis" remains firmly established in the literature, although involvement of muscle fibres occurs only in a secondary fashion. McKusick (1960) included the disease among the likely hereditary disorders of connective tissue probably inherited as a Mendelian dominant with irregular penetrance. The diagnosis depends upon clinical and radiclogical examination, the changes in the latter being outstanding when the disease is advanced. The cardinal feature is ectopic ossification frequently associated with congenital anomalies of the digits, especially the thumb and great toe. The pathological process is well defined. Ectopic ossification begins in the fascia, muscle tendons, and aponeuroses, usually before the age of 10 years, or even during foetal life (Hutchinson, 1860; Rosenstirn, 1918; Mair, 1932). More rarely it is delayed until after the age of 20 years (Frejka, 1929; Hirsch and Löw-Beer, 1929). Although remissions may occur in the early stages of the disease, its progress is relentless until the patient is immobilized by plates of bone replacing tendons, fasciae, and ligaments. No treatment yet available can influence the endresult of bedridden helplessness. Death usually results from respiratory embarrassment or from inanition due to involvement of the masseter and temporalis muscles. Nevertheless, it is remarkable that some of these patients have survived to middle age or longer in spite of severe disablement, e.g. 51 years at least in the case described by Koont $z$ (1927) and 61 years in a case described by Fairbank (1951).

Clinical Features.-These can be conveniently considered under two headings.

(1) Congenital anomalies of the skeleton are important, for they can be recognized at birth or before ectopic ossification makes the diagnosis obvious. Helferich (1879) first pointed out the association of microdactyly with the condition. The great toe is most frequently affected, the thumb in about half the cases, and at times other digits (McKusick, 1960). Hallux valgus is almost always present. Clinodactyly may also occur. These bony abnormalities are usually symmetrical. Exostoses may develop, usually replacing sesamoid bones.

(2) The effects of the process of ectopic ossification. In the early stages of the disease in children, localized painful swellings may appear, especially in the neck, back, and limbs. Their appearance may be related to minor trauma. The swellings may contain blood and they may ulcerate and discharge their contents. During their formation and absorption systemic effects may occur with joint pains and pyrexia resembling rheumatic fever (Ryan, 1945). Involvement of the sternomastoid muscles leads to typical wryneck deformity. The plantar and palmar fasciae may be involved. According to McKusick (1960), the tongue, larynx, heart, diaphragm, sphincters, eye muscles, perineal muscles, and abdominal wall muscles enjoy immunity from the disease. In the advanced stage of the disease the trunk is enveloped in sheets of bone. 


\section{Case Report}

The patient was first seen in Hospital at the age of 5 years with a history of pains in the limbs and a painful wryneck. Fig. 1 illustrates torticollis at this time before a corrective operation for this condition. During his school days from 6 to 14 years his arms were always weak and sometimes sore, and he frequently had "lockjaw" so that he had difficulty in swallowing solids. From the age of 14 to 22 years he worked as a clerk, but during these years his limbs stiffened up, and at the age of 24 years he was so "doubled up" according to his own description, that he was completely helpless. He was bedridden for the next 16 years and was cared for at home by his mother until admitted to Hospital as an emergency at the age of 40 years. The reason for hospitalization was that feeding became impossible as his jaws were tightly clenched and could not be separated. Fig. 2 illustrates his general appearance at this time.

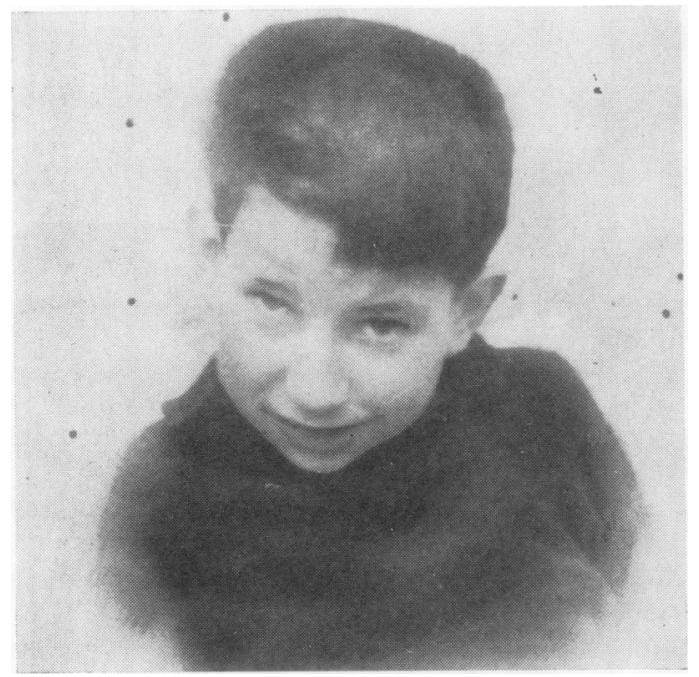

Fig. 1.-Torticollis in a patient aged 5 years.
He was helpless and had no movement at any of the large joints of the limbs. The spine was rigid and he could not move his head. There was gross muscle wasting and stony hard masses were palpable in the shoulder girdle and on the back of the thorax and in the lumbar region. It was not possible to separate his edentulous gums and nutrition was maintained by tube feeding of fluids round the outer margins of the gums. There was no sphincter disturbance and, in spite of years in bed, there were no bed sores. The muscles of expression in the face and the eye muscles were functioning normally. Each foot showed an extreme degree of hallux valgus and the other digits showed hammer toe deformities; great toes were normal in length. The left hand only showed clinodactyly of the little finger. Each thumb appeared to be of normal length and appeared to consist of a single bone due to synostosis of the phalanges. The heart sounds were normal, and there were no cardiac murmurs. The blood pressure was $130 / 70 \mathrm{~mm}$. $\mathrm{Hg}$, and there was normal arterial pulsation in the limbs.

Radiological Changes.-In spite of the patient's incapacity a radiological survey of all regions of the body was carried out for evidence of the distribution of ectopic ossification and congenital skeletal abnormalities. Plates of bone replaced the muscles of the shoulder girdles and thoracic wall. The lumbar muscles were also replaced by bone. There were no deposits of bone in the neck, anterior abdominal wall, or lower limbs. Ectopic ossification is shown in Figs 3 and 4 (opposite) and Fig. 5 (overleaf).

An incidental finding in Fig. 3 was a right-sided aortic arch. Tomography showed no evidence of ossification of heart muscle. The abnormalities of the skeleton are shown in Figs 6 and 7 (overleaf).

Fig. 3.-Right-sided aortic arch. Thick plates of bone anchor the humeri to the thoracic wall. The left ribs are thin and malformed. Fused ribs can be seen on both sides. The left shoulder joint is ankylosed, and the left humerus malformed and atrophic.

Fig. 4.-Plates of bone anchor the pelvic bones to the femur on each side. The hip joints are ankylosed. The femoral heads are osteoporotic.

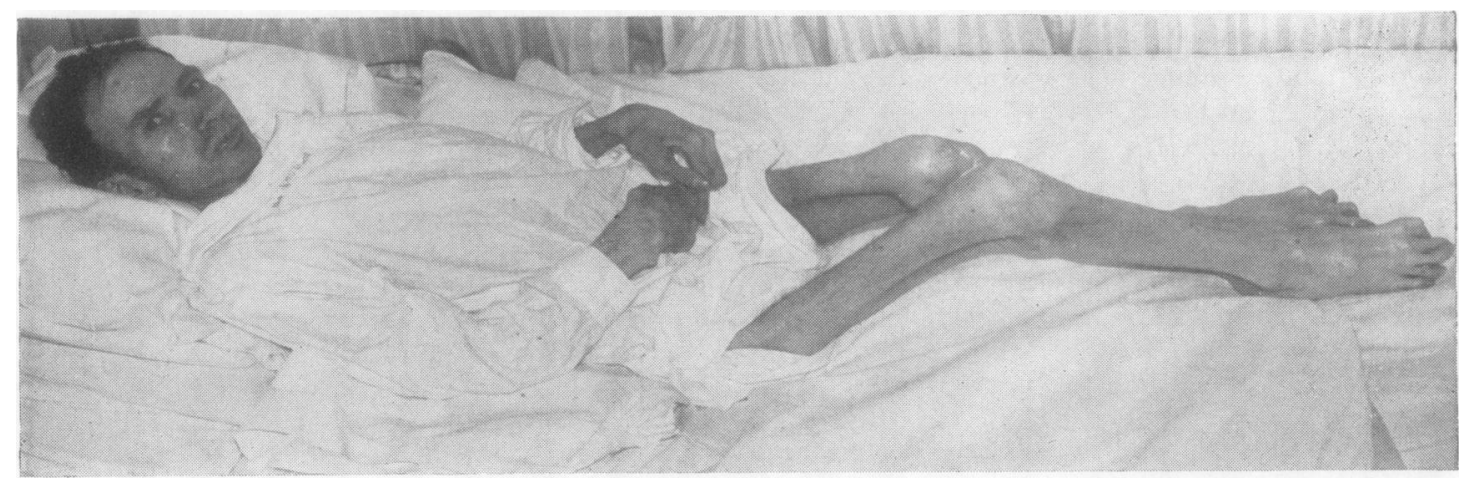

Fig. 2.-Patient bedridden, aged 40 years. Note deformity of great toe. Intelligent face. Jaws clenched tight and immobile. Ocular muscles and facial muscles of expression normal. 


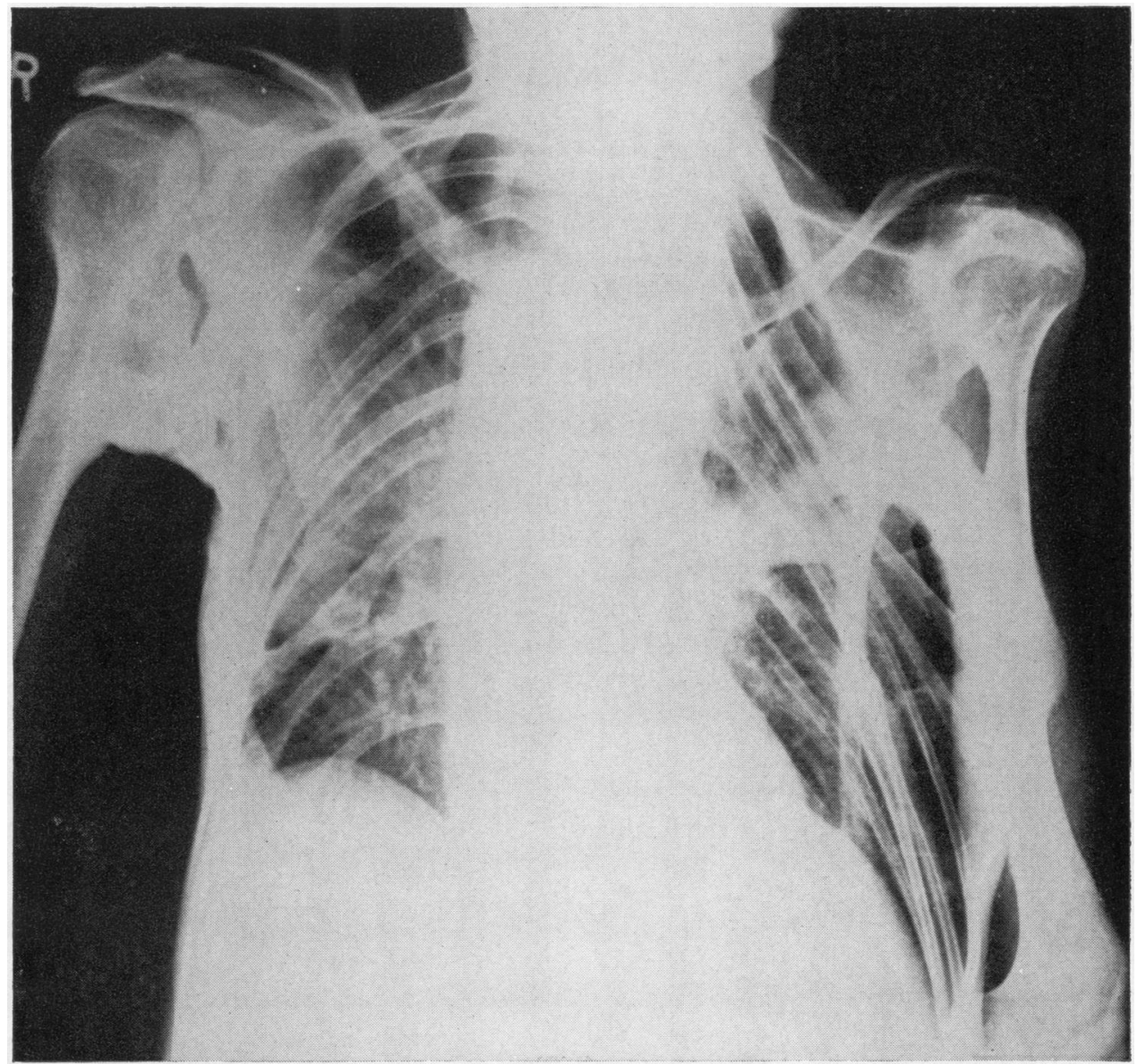

Fig. 3

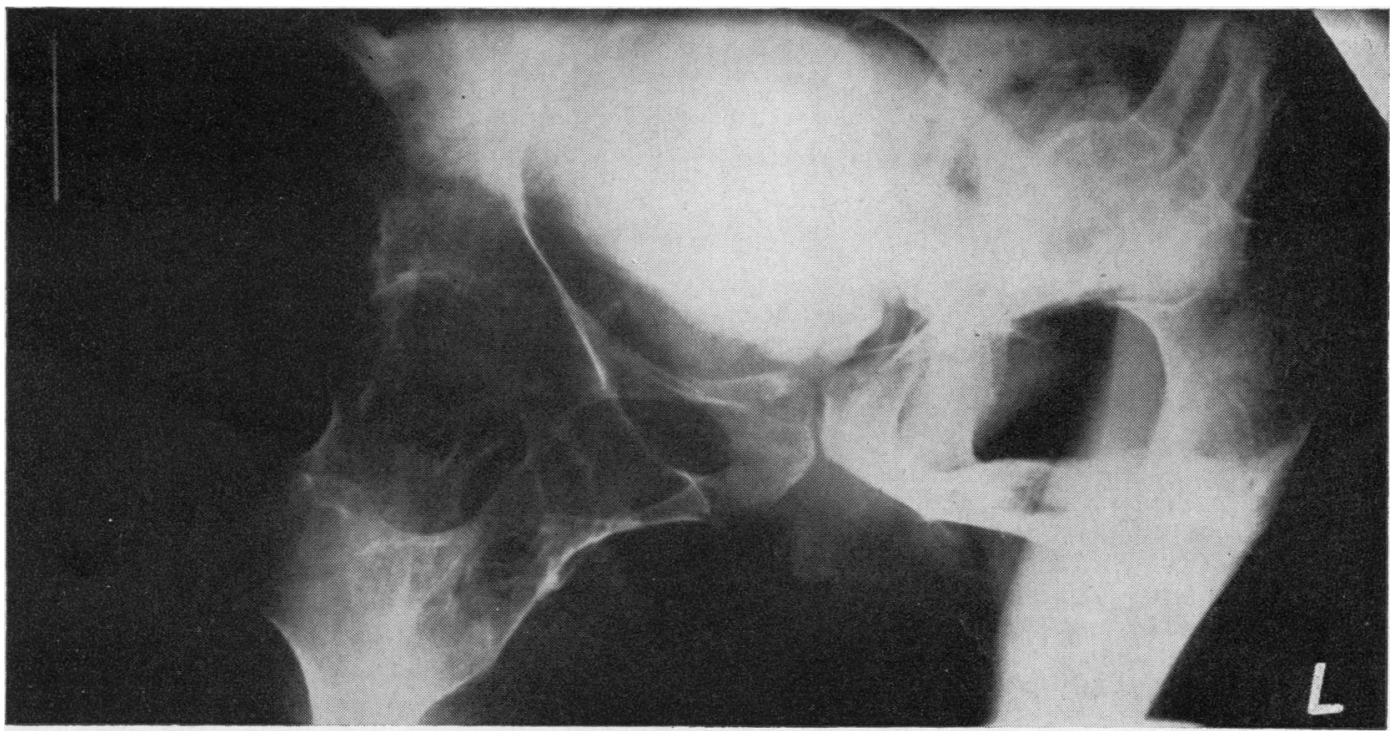




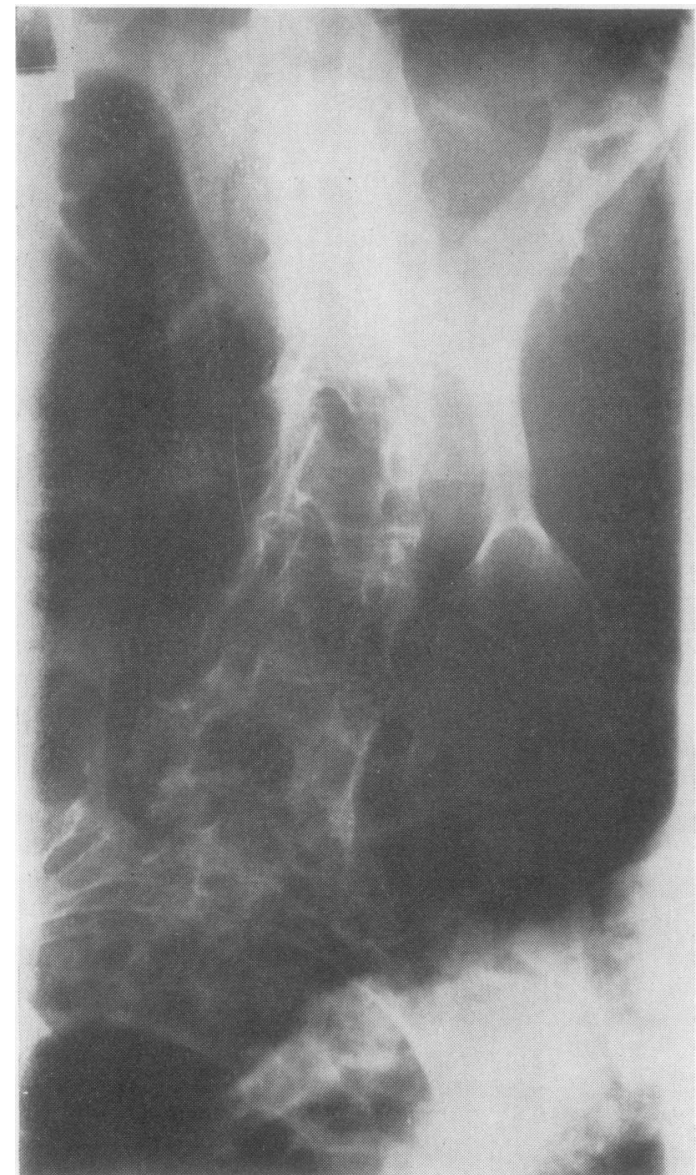

Fig. 5.-A plate of bone connects the crest of the ilium to the back of the lower ribs. Note also advanced spondylosis with scoliosis and osteoporosis of lumbar spine.

Laboratory Findings.-Price's precipitation reaction and the Wassermann reaction were negative.

Serum calcium $9.5 \mathrm{mg}$. per cent., serum phosphate 3.8 mg. per cent., serum proteins total $8 \cdot 3 \mathrm{~g}$. per cent. (albumin 4.3 g., globulins 4 g.), serum electrophoresis showed increase in alpha ${ }_{2}$ globulin and slight increase in gamma globulin. Alkali reserve $28 \mathrm{mEq} /$ litre, serum sodium $132 \mathrm{mEq} /$ litre, serum potassium $4 \cdot 2 \mathrm{mEq} /$ litre, serum chloride $88 \mathrm{mEq} /$ litre. Blood urea $34 \mathrm{mg}$. per cent. Serum alkaline phosphatase $10 \mathrm{King}$ Armstrong units, serum acid phosphatase 9 King Armstrong units. S.G.O.T. 34 units, Serum aldolase 13 units $/ \mathrm{ml}$. (normal 3-8 units/ml.; Bruns, 1954).

Urinary amino-acid chromatogram showed general amino-aciduria. Urinary 17 -ketosteroids $2 \cdot 3 \mathrm{mg} \cdot / 24 \mathrm{hrs}$, 17-ketogenic steroids $2.6 \mathrm{mg}$. $/ 24 \mathrm{hrs}$, urinary creatinine $100 \mathrm{mg}$. per cent., creatinine co-efficient $3 \cdot 5$ (normal 7-10).

Haemoglobin 98 per cent. (Sahli), bleeding time and clotting times normal.

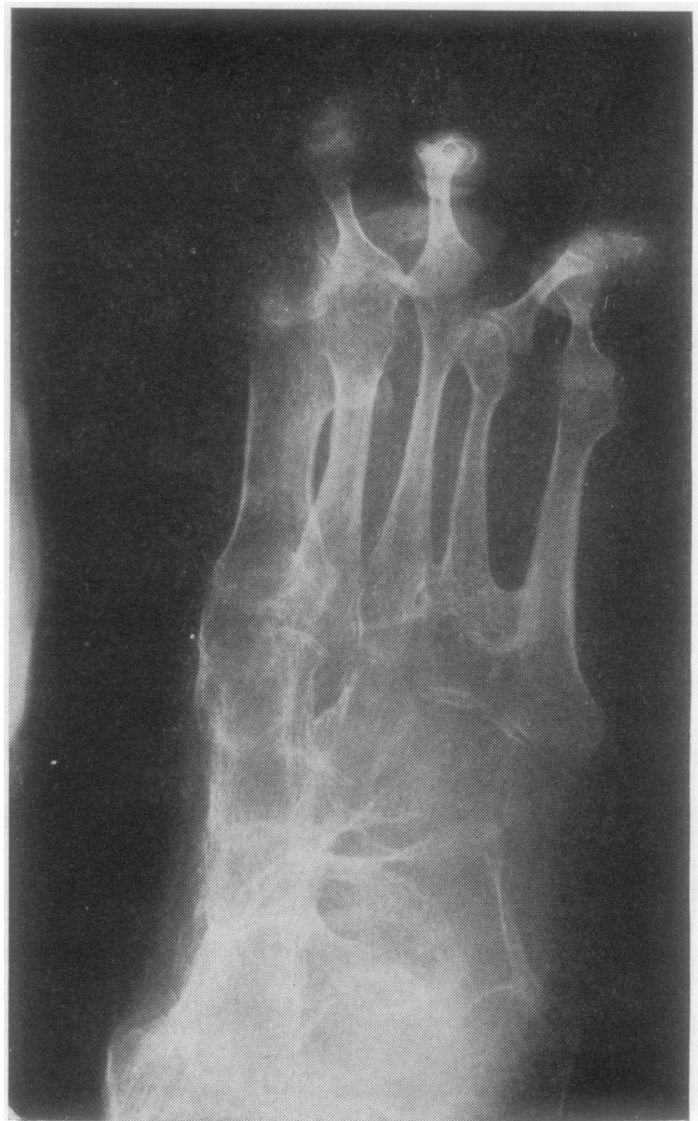

Fig. 6.-Right foot. The proximal phalanx of the great toe is malformed and fused with the adjacent metatarsal bone (synostosis). The second phalanx is subluxated laterally dorsal to the second and third toes giving rise to extreme hallux valgus. The fourth toe is subluxated laterally at the metacarpophalangeal joint. The second, third, and fifth toes have hammer toe deformities. The third, fourth, and fifth metatarsal bones are webbed together by new bone formation at their bases. A large exostosis at the head of the first metatarsal bone projects laterally beneath the second metatarsal bone.

Muscle Biopsy.-Pectoralis major muscle fibres show variation in size, some of them being very small. This change is associated with sarcolemma proliferation and some fibrosis. There is no arteritis or interstitial inflammatory cell infiltration. The appearances are consistent with a diagnosis of muscular dystrophy.

Electrocardiogram.-The tracing (Fig. 8, opposite) is grossly abnormal. There is a minor degree of intraventricular block, and abnormal repolarization of the ventricles producing abnormal S-T segment changes. As the patient was not receiving any cardiac drugs, primary myocardial disease appears to be present.

\section{Discussion}

The classical clinical and radiological features of myositis ossificans progressiva were present in the case described. Torticollis in early childhood is 


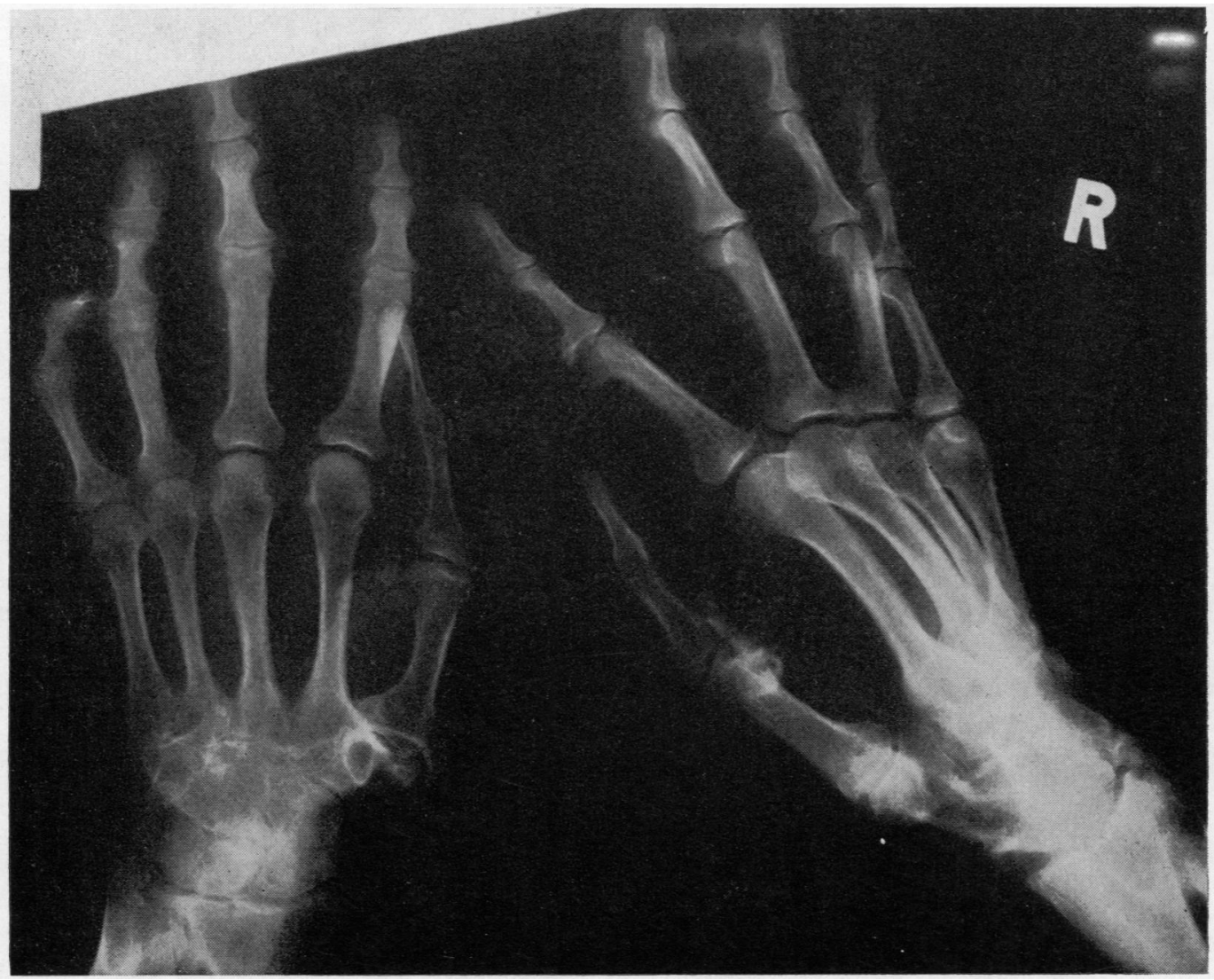

Fig. 7.-Each thumb has two phalanges but the interphalangeal joints are rudimentary (synostosis). The left little finger has a curved deformity (clinodactyly). The base of the metacarpal bone of the left thumb is malformed. A large exostosis at the head of the metacarpal bone of the right thumb is astride the metacarpophalangeal joint. The first and second phalanges of the index finger of the right hand also have exostosis at the interphalangeal joint.
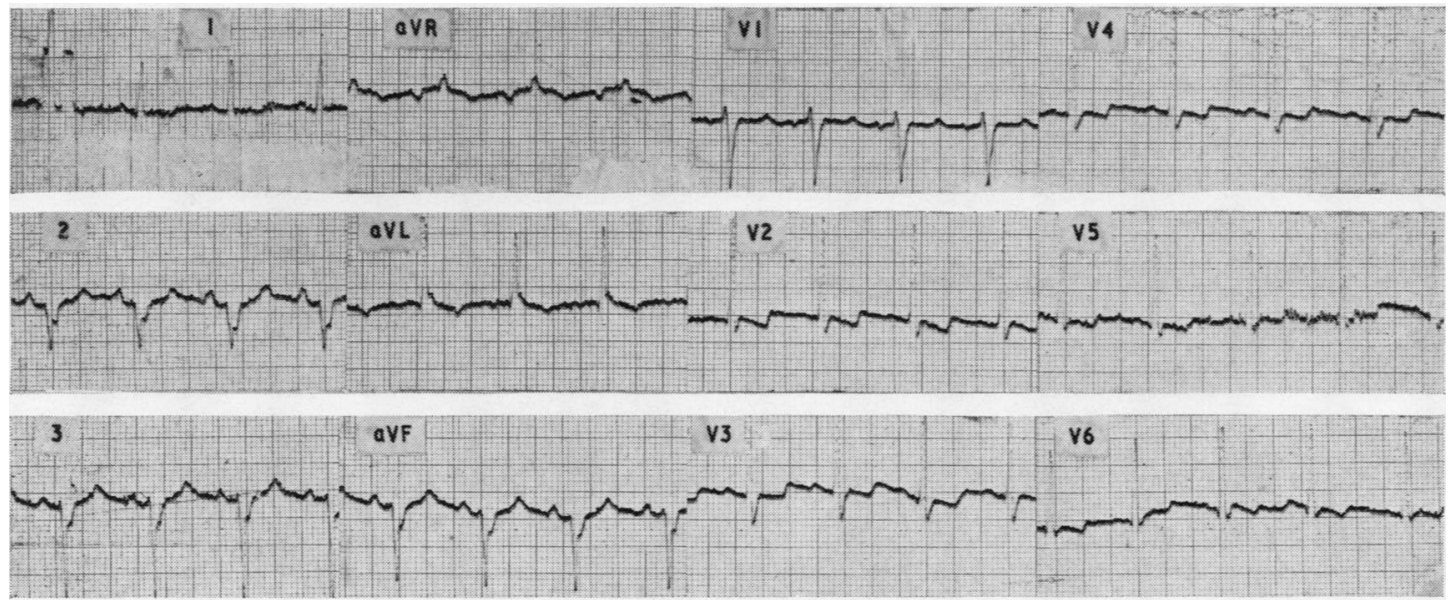

Fig. 8.-Electrocardiogram. Sinus rhythm, rate 90 per min. P-R interval $0 \cdot 16$ sec. QRS interval $0 \cdot 1$ sec. Terminal portions QRS complexes notched in Leads 2 and 3, and in the unipolar limb leads indicating a minor degree of intraventricular block. There is marked left axis deviation. The S-T segments are abnormally displaced in most leads. The tracing is grossly abnormal and indicates myocardial impairment. 
noteworthy. Trismus due to involvement of the muscles of mastication was the ultimate factor which determined urgent admission to hospital. The histopathology of the condition was first described by Virchow (1894). Nuclei are scanty in involved muscle fibres and hyaline degeneration of the sarcoplasm occurs. The tendon and muscle substance is replaced by basophilic collagen-like material with punctate calcification. When extensive ossification has occurred the material deposited is indistinguishable from normal bone; osteocytes are seen, and Haversian lucanae are present; a bone marrow cavity is present with normal bone marrow; osteoblasts and osteoclasts are found in normal proportions. Occasionally the condition may mimic osteogenic sarcoma (Paul, 1925). Biochemical investigations have usually been unrewarding, but the reader is referred to the current investigations of Lutwak (1964) for the study of the effects of steroids and other hormones and drugs on the condition. In our case, a raised serum aldolase and low levels of ketosteroid excretion and low creatinine coefficient were the only biochemical alterations which may be of interest. Two attempts at calcium balance studies were unsuccessful on account of the patient's total incapacity. Microdactyly was not present. The thumbs and great toes showed congenital abnormalities which were symmetrical, but the clinodactyly of the little finger was asymmetrical, which is unusual. Another unusual finding was the presence of a right-sided aorta and a grossly abnormal electrocardiogram. Lutwak (1964) has also noted an abnormal electrocardiogram in one of his cases. Whether these changes indicate a fibrodysplasia of the myocardium as part of the disease process will remain a matter of conjecture until pathological studies are available.

Finally, familial instances of the disease have been described (Burton-Fanning and Vaughan, 1901; Gaster, 1905), and identical twins may be affected (Vastine, Vastine, and Arango, 1948; Eaton, Conkling, and Daeschner, 1957).

\section{Summary}

A description of the clinical and radiological features of myositis ossificans progressiva is given. Torticollis in childhood and trismus with total incapacity in adult life were important disabilities. Extensive ectopic ossification developed and congenital abnormalities of the skeleton were present, including synostosis of the thumbs, asymmetrical clinodactyly, and marked hallux valgus. An unusual finding was a right-sided aortic arch and a grossly abnormal electrocardiogram.
We should like to acknowledge the help given us by Mr. S. G. Welshman, M.Sc., A.R.I.C., of the Belfast Central Laboratory, Belfast City Hospital.

\section{REFERENCES}

Bauer, K. H., and Bode, W. (1940). In "Handbuch der Erbbiologie des Menschen", ed. G. Just, band 3: "Erbbiologie and erbpathologie körperlicher Zustände and Funktionen", vol. 1, p. 105. Springer, Berlin.

Bruns, F. (1954). Biochem. Z., 325, 156.

Burton-Fanning, F. W., and Vaughan, A. L. (1901). Lancet, $2,849$.

Eaton, W. L., Conkling, W. S., and Daeschner, C. W. (1957). J. Pediat., 50, 591.

Fairbank, H. A. T. (1951). "An Atlas of General Affections of the Skeleton". Livingstone, Edinburgh.

Frejka, B. (1929). J. Bone Jt Surg., 11, 157.

Gaster, A. (1905). W. Lond. med. J., 10, 37.

Helferich, H. (1879). Ärztl. Intelligenz-Blatt., 26, 485.

Hirsch, F., and Löw-Beer, A. (1929). Med. Klin., 25, 1661.

Hutchinson, J. (1860). Med. Tms (Lond.), 317.

Koontz, A. R. (1927). Amer. J. med. Sci., 174, 406.

Lutwak, L. (1964). Amer. J. Med., 37, 269.

Mair, W. F. (1932). Edinb. med. J., 39, 13, 69.

McKusick, V. A. (1960). "Heritable Disorders of Connective Tissue", 2nd ed. Mosby, St. Louis.

Paul, J. R. (1925). Arch. Surg., 10, 185.

Rosenstirn, J. (1918). Ann. Surg., 68, 485, 591.

Ryan, K. J. (1945). J. Pediat., 27, 348.

Vastine, J. H., Vastine, M. F., and Arango, O. (1948). Amer. J. Roentgenol., 59, 204.

Virchow, R. (1894). Berl. klin. Wschr., 31, 727.

\section{Myositis ossificans progressiva}

\section{RÉSUMÉ}

On décrit les traits cliniques et radiologiques de la myosite ossifiante progressive. Le torticolis pendant l'enfance et le trismus avec incapacité totale pendant la vie adulte étaient des causes importantes de l'infirmité. L'ossification ectopique étendue se développait et des anomalies congénitales du squelette étaient présentes, y compris la synostose des pouces, la clinodactylie asymétrique et l'hallux valgus prononcé. Comme trouvaille extraordinaire on a noté la crosse de l'aorte á droite et un électrocardiogramme très anormal.

\section{Myositis ossificans progressiva}

\section{SUMARIO}

Se describen los rasgos clínicos y radiológicos de la myositis ossificans progressiva. El torticolis en la infancia y el trismo con incapacidad total en la vida adulta fueron causas mayores de invalidez. La osificación ectópica extensa se desarrolló y anomalías congénitas del esqueleto fueron presentes, con sinostosis de los pulgares, clinodactilia asimétrica y hallux valgus pronunciado. Hallazgos extraordinarios fueron el cayado de la aorta a la derecha y un electrocardiogramo muy anormal. 